\title{
Solvent-Controlled Hydrogenation of 2'-Hydroxychalcones: A Simple Solution to the Total Synthesis of Bussealins
}

\author{
Martín Soto, ${ }^{\text {a }}$ Raquel G. Soengas, ${ }^{\mathrm{a}, *}$ and Humberto Rodríguez-Solla ${ }^{\mathrm{a}, *}$ \\ a Departamento de Química Orgánica e Inorgánica, Universidad de Oviedo, Julián Clavería 7, 33006, Oviedo, Spain \\ E-mail: hrsolla@uniovi.es; rsoengas@uniovi.es
}

Manuscript received: July 29, 2020; Revised manuscript received: September 4, 2020;

Version of record online:

Supporting information for this article is available on the WWW under https://doi.org/10.1002/adsc.202000892

\begin{abstract}
A solvent-controlled hydrogenation of 2'-hydroxychalcones to selectively obtain different hydrogenation products is herein reported. Thus, hydrogenation of 2'-hydroxychalcones using EtOH as solvent provided the corresponding 1,3-diarylpropanes in excellent yields. On the contrary, when the hydrogenation was performed in DCM, the corresponding dihydrochalcones were isolated. Switching the reaction solvent to $n$ - $\mathrm{BuOH} / \mathrm{H}_{2} \mathrm{O}$ (1:1), afforded 1,3-diarylpropanols from moderate to good yields. The methodology here reported offers a straightforward, simple and cost-effective method for the preparation of a wide variety of 2'hydroxy-1,3-diarylpropanes derivatives, and was also applied to the preparation of natural Bussealins C and D.
\end{abstract}

Keywords: Bussealins; Chalcones; Green Solvents; Hydrogenation; Palladium

\section{Introduction}

1,3-Diarylpropanes are a subclass of flavonoids which are important secondary metabolites of plants. These compounds are precursors in the flavonoid biosynthesis and have been isolated from diverse plant species from around the globe. ${ }^{[1]}$ 1,3-Diarylpropanes exhibit diverse biological activities, i.e. antifungal ${ }^{[2]}$ anti-inflammatory, ${ }^{[3]}$ anticancer, ${ }^{[4]}$ antiadipogenic, ${ }^{[5]}$ antitubercular, ${ }^{[6]}$ antimalarial, ${ }^{[7]}$ and anti-Alzheimer ${ }^{[8]}$ to name a few. Owing to their wide range of bioactivities, 1,3-diarylpropanes have become of great interest to many research groups in chemistry, biomedicine as well as those in agricultural and food chemistry. An interesting example of naturally-occurring 1,3-diarylpropanes is the Bussealin family (Figure 1).

These natural products were first isolated in 2007 from the roots of the endemic Malagasy plant Bussea sakalava $^{[9]}$ and display low micromolar levels of activity against various cancer cell lines. ${ }^{[9,10]}$

Despite the promising biological profile of bussealins, the lack of short, efficient and high yielding synthetic routes have precluded a more thorough biological assessment.

As it has been previously reported, 2'-hydroxy-1,3diarylpropanes were prepared either by direct cinnamylation of phenols and catalytic hydrogenation of the

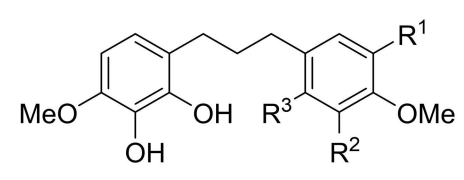

Bussealins:

A $\mathrm{R}^{1}=\mathrm{R}^{2}=\mathrm{OH} ; \mathrm{R}^{3}=\mathrm{H}$

B $\mathrm{R}^{1}=\mathrm{OH} ; \mathrm{R}^{2}=\mathrm{H} ; \mathrm{R}^{3}=\mathrm{OMe}$

C $\mathrm{R}^{1}=\mathrm{R}^{3}=\mathrm{H} ; \mathrm{R}^{2}=\mathrm{OH}$

D $\mathrm{R}^{1}=\mathrm{R}^{3}=\mathrm{OMe} ; \mathrm{R}^{2}=\mathrm{H}$

Figure 1. Bussealin natural products A-D.

resulting cinnamyl phenols ${ }^{[11]}$ or through the addition of aryl lithium reagents to 3-arylpropanal followed by catalytic hydrogenation. ${ }^{[12]}$ Both procedures afforded the 2'-hydroxy-1,3-diarylpropanes in low yields (ranging from 5 to $23 \%$ ).

Conceptually, the total reduction of the enone group of chalcones would be the easiest way to access 1,3diarylpropanes. However, the methods reported in the literature have important limitations, especially when applied to the synthesis of 2'-hydroxy substituted derivatives. Thus, catalytic hydrogenation of chalcones over $\mathrm{Pd} / \mathrm{C}$ in acetic acid yielded desired 1,3-diarylpropanes, albeit in moderate yields. ${ }^{[13]}$ The use of more active $\mathrm{Pd}(\mathrm{OH})_{2}$ catalyst in mixtures of organic solvents and water failed to improve the yields. ${ }^{[14]}$ 
Better results were obtained when the catalytic hydrogenation was carried out under high hydrogen pressure. In this sense, the total reduction of chalcones was achieved on catalytic hydrogenation over $\mathrm{Pd} / \mathrm{C}$ with hydrogen at $50 \mathrm{psi}$ in mixtures of chloroform, water and acetic acid. The yields were good, except for chalcones bearing an unprotected 2'-hydroxyl group. ${ }^{[15]}$

In order to overcome the limitations of the direct route for the total hydrogenation of chalcones to diarylpropanes when applied to 2'-hydroxyl substituted substrates, the two-step reduction of the enone group was then considered. In this regard, two different strategies were previously investigated: i) the hydrogenation of chalcones to the corresponding dihydrochalcones followed by reduction to the desired diarylpropanes $;{ }^{[16]}$ and ii) the reduction of the carbonyl group of chalcones and further hydrogenation of the resulting cinnamyl arenes.

As a recent example of the first strategy, Wu et al. investigated the use of a $\mathrm{Ni}-\mathrm{Al}$ alloy for the reduction of the hydrochalcones to the corresponding 1,3-diarylpropanes. Again, the reaction was problematic for 2'hydroxyhydrochalcones in which reaction was not observed. This fact was attributed to conjugation and chelation effects. Subsequently, 2'-hydroxyhydrochalcones required treatment with trifluroacetic acid (TFA) and triethylsilyl hydride $\left(\mathrm{Et}_{3} \mathrm{SiH}\right)$ at $50-55^{\circ} \mathrm{C}$ to accomplish the reduction and provide desired 2'hydroxy-1,3-diphenylpropanes.

Regarding the second strategy, Zhang and coworkers investigated the synthesis of cinnamyl phenols by the means of a Luche reduction of chalcones. ${ }^{[17]}$ From cinnamyl phenols, 2'-hydroxy-1,3-diarylpropanes would be easily available on catalytic hydrogenation. The synthesis of cinnamyl phenols can also be carried out by a $s p^{2}-s p^{3}$ Hiyama type cross-coupling of vinyl disiloxanes with benzylic bromides. This strategy was developed by Spring et al. ${ }^{[10]}$ and then applied to the synthesis of bussealins A and E. Despite the cross-coupling key reaction is very effective in constructing the diarylpropane moiety, the synthesis of the starting disiloxanes is rather long and time consuming ( 8 steps, $28 \%$ overall yield). ${ }^{[18]}$

Considering the potential biological applications of bussealins and to have sufficient material for a complete pharmacological assessment, it is crucial to have a straightforward and high yielding route to these natural products. For this purpose, we decided to reinvestigate the hydrogenation of 2'-hydroxy chalcones.

In the work herein presented we investigate the effect of the solvent in the hydrogenation of 2'hydroxychalcones using palladium-on-carbon catalyst. This knowledge has been applied to the synthesis of different interesting compounds including the synthesis of Bussealins C and D.

\section{Results and Discussion}

It is widely known that solvents have a significant effect on heterogeneous catalysis. ${ }^{[19]}$ In the case of catalytic hydrogenation on heterogeneous conditions, the dependence of the hydrogenation rate with the solvent can be attributed to a combination of four main factors: hydrogen solubility, vapor pressure, viscosity and interactions with the reactants. ${ }^{[20]}$ The first three factors are related to the rate of supply of hydrogen at the catalytic surface. The concentration of hydrogen in the solvent would depend on the partial pressure of hydrogen in the gas phase and the solubility coefficient. Moreover, the rate of transport from the gas phase through the solvent to the catalytic site will depend on the viscosity of the solvent. ${ }^{[21]}$ On addition, catalytic hydrogenation rate is also affected by solvent interactions with reactants. It is widely known that protic solvents interact with substrates containing a carbonyl function through hydrogen bonding, increasing the electrophilicity of the carbonyl-carbon and therefore the rate of the hydrogenation. ${ }^{[22]}$ Thus, competition of the chalcone substrate and the solvent for catalyst adsorption sites can impact on hydrogenation rate. An increased surface affinity for the solvent would inhibit chalcone activation, resulting in lower reaction rate. ${ }^{[23]}$ Water and alcohols can adsorb on the catalyst surface through the oxygen of the hydroxyl group; the greater electron density of the hydroxyl oxygen in alcohols results in a stronger interaction that increases when also increasing alcohol chain length. ${ }^{[24]}$

For a given reaction, a deep knowledge of how all these factors affect the catalytic process would allow the design of an optimal solvent or solvents mixture. Accordingly, in order to optimize the hydrogenation of 2'-hydroxychalcones we decided to investigate the effect of the solvents and how a combination of the above factors would affect the rate of the reaction. Solvent selection has been made considering the growing concern in solvent greeneness, ${ }^{[25]}$ particularly in the pharmaceutical industry. ${ }^{[26]}$

Pharmaceutical industry uses solvent selection guides to aid the selection of solvents with low toxicity, minimal safety concerns and little impact on the environment. ${ }^{[27]}$ Using these guides, we selected for our study several solvents from different classes; in addition to the most familiar green solvents water and ethanol, $n$-butanol, ${ }^{[28]}$ 2-methyltetrahydrofuran (2MeTHF) ${ }^{[29]}$ and heptane were also considered. ${ }^{[25]}$

Thus, a mixture of 2'-hydroxychalcone $\mathbf{1}$ a and $\mathrm{Pd} /$ C $10 \%(20 \% \mathrm{~mol})$ in various solvents was stirred under hydrogen atmosphere at r.t. for $24 \mathrm{~h}$. As depicted in Table 1, solvents significantly showed influence in the hydrogenation rate and thus the yield and distribution of the hydrogenation products. 
Table 1. Studies on the hydrogenation of 2'-hydroxychalcone $\mathbf{1}$ a.
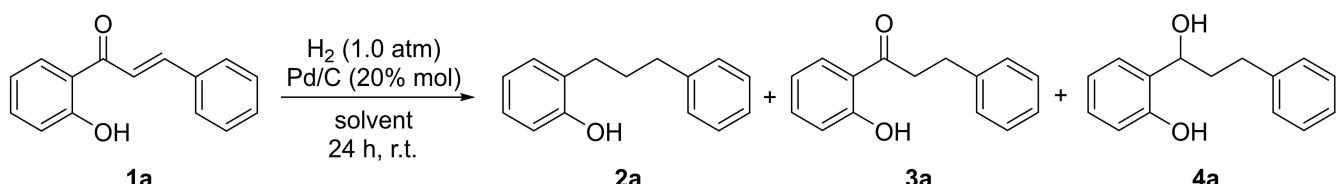

$1 \mathrm{a}$

$2 a$

$4 a$

\begin{tabular}{|c|c|c|c|c|}
\hline \multirow[t]{2}{*}{ Entry } & \multirow[t]{2}{*}{ Solvent } & \multicolumn{3}{|c|}{ Conversion $[\%]^{[a]}$} \\
\hline & & $2 \mathbf{a}$ & $3 \mathbf{a}$ & $4 a$ \\
\hline 1 & $\mathrm{EtOH}$ & $>98$ & 0 & 0 \\
\hline 2 & $\mathrm{EtOH}^{[\mathrm{b}]}$ & 25 & 60 & 15 \\
\hline 3 & 2-MeTHF & 11 & 67 & 22 \\
\hline 4 & Heptane & 33 & 48 & 19 \\
\hline 5 & DCM & 0 & $>98$ & 0 \\
\hline 6 & $\mathrm{DCM}^{[\mathrm{b}]}$ & 0 & $>98$ & 0 \\
\hline 7 & $\mathrm{H}_{2} \mathrm{O}$ & 31 & 44 & 24 \\
\hline 8 & $n-\mathrm{BuOH}$ & 10 & 56 & 33 \\
\hline 9 & $n-\mathrm{BuOH} / \mathrm{H}_{2} \mathrm{O}(1: 1)$ & 0 & 0 & $>98$ \\
\hline 10 & $n-\mathrm{BuOH} / \mathrm{H}_{2} \mathrm{O}(2: 1)$ & 95 & 0 & 5 \\
\hline 11 & $n-\mathrm{BuOH} / \mathrm{H}_{2} \mathrm{O}(1: 2)$ & 65 & 0 & 35 \\
\hline 12 & $n-\mathrm{BuOH} / \mathrm{H}_{2} \mathrm{O}(1: 1)^{[\mathrm{b}]}$ & 0 & 35 & 65 \\
\hline
\end{tabular}

${ }^{[a]}$ Conversions determined by ${ }^{1} \mathrm{H}$ NMR $(300 \mathrm{MHz})$ of the crude reaction mixtures based on compound $1 \mathbf{a}$.

${ }^{[b]}$ Reactions performed at $6 \mathrm{~h}$.

It was observed that thermodynamic interactions of the solvent with reactants and products, and hydrogen supply are the preeminent factors controlling the hydrogenation of 2'-hydroxychalcone $\mathbf{1}$ a. Therefore, the hydrogenation rate is high in higher-polarity solvents with a good $\mathrm{H}_{2}$ solubility, whereas a low hydrogenation rate was observed in non-polar solvents with a poor hydrogen solubility (Figure 2). Hydrogenation of 2'-hydroxychalcone $\mathbf{1}$ a in $\mathrm{EtOH}$ afforded the total reduction product $\mathbf{2}$ a almost quantitatively (Table 1, entry 1 ), whereas performing the hydrogenation in dichloromethane led selectively to dihydrochalcone $\mathbf{3 a}$ in excellent yield (Table 1, entry 5). Switching from DCM to the greener alternative, polar aprotic solvent 2-MeTHF, the hydrogenation reaction gave a mixture of the three possible reduction products $\mathbf{2} \mathbf{a}$, $\mathbf{3 a}$ and $\mathbf{4} \mathbf{a}$ in a rate 11:67:22 (Table 1, entry 3 ). Nonpolar heptane showed a slightly higher hydrogenation rate on account of its very high hydrogen solubility (Table 1, entry 4). When the hydrogenation was carried out in water, the reduction was less effective when compared with the same process performed in ethanol (Table 1, entry 7). Even if water can interact with the chalcone more effectively than ethanol, limited solubility of both hydrogen and chalcone in water rendered the reduction process less effective. In contrast with ethanol, other alcoholic media as $n$ butanol afforded very poor results comparable to those
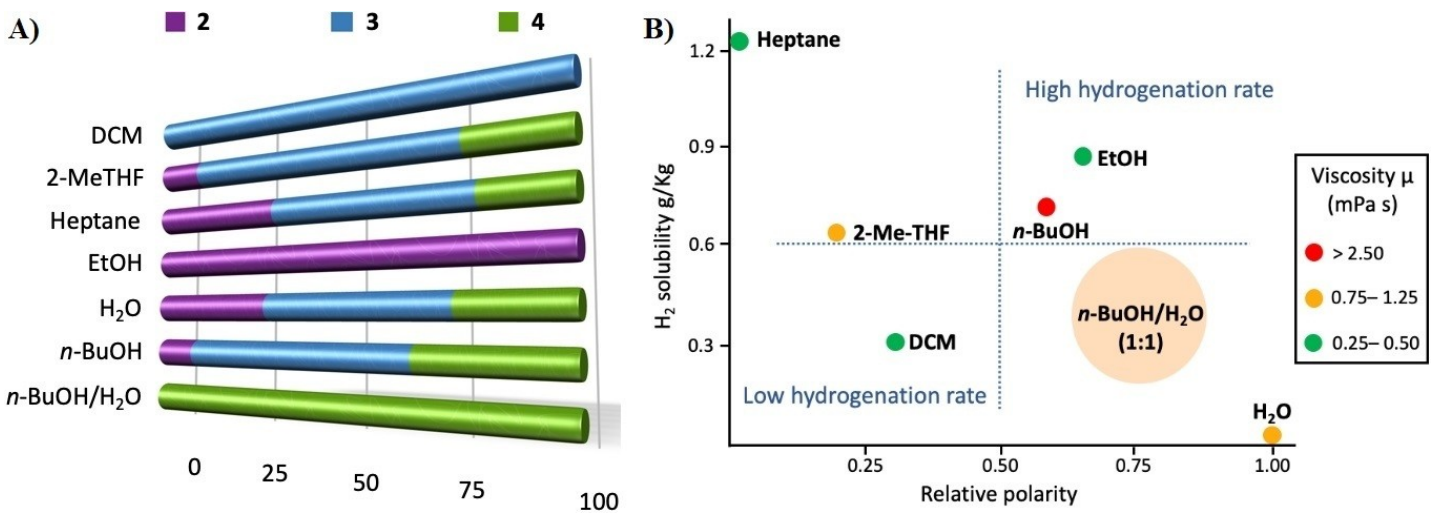

Figure 2. A) Selectivity of the hydrogenation of 2'-hydroxychalcone $\mathbf{1}$ a in different solvents. B) Graph showing the relative rate of hydrogenation of 2'-hydroxychalcone $\mathbf{1}$ a as a function of the hydrogen solubility and polarity of the solvent. Colours indicate the viscosity of the solvent. ${ }^{[28]}$ 
observed when the reaction was performed in 2MeTHF (Table 1, entry 8).

This result can be attributed to the very high viscosity of $n$-butanol and, consequently, to the low transportation rate of hydrogen to the catalytic site. In an attempt to lower viscosity without lowering the polarity, water was added as an additive. Interestingly, when the hydrogenation was performed in $n$-butanol/ $\mathrm{H}_{2} \mathrm{O}$ (1:1), 1,3-diarylpropanol 4 a was selectively obtained in an excellent yield (Table 1, entry 9). Using $n$-butanol/ $\mathrm{H}_{2} \mathrm{O}$ at different ratios $(2: 1$ or $1: 2)$ have a deleterious effect on the selectivity (Table 1, entries 10 and 11). Attempts to decrease the reaction time from 24 to $6 \mathrm{~h}$ also resulted, in general terms, in a decrease of the selectivity (Table 1, entries 2 and 12) excepting for the case of DCM, where decreasing the reaction time to $6 \mathrm{~h}$ allowed the isolation of $\mathbf{3 a}$ as the sole product (Table 1 , entry 6 ).

Once we had determined that ethanol is the solvent of choice for the total enone reduction, we decided to investigate the effect of the catalyst loading in the reduction of chalcone $\mathbf{1}$ a to 1,3-diarylpropane $\mathbf{2}$ a. The presence of a $20 \%$ mol catalyst loading is essential for the formation of the desired product $\mathbf{2}$ a; using $10 \%$ or $5 \% \mathrm{~mol}$ of $\mathrm{Pd} / \mathrm{C}$, the hydrogenation reaction afforded a nearly 9:1 mixture of the dihydrochalcone $\mathbf{3 a}$ and the 1,3-diarylpropane $\mathbf{2}$ a (Table 2, entries 2 and 3).

With the optimal conditions for the formation of the 1,3-diarylpropanes $\mathbf{2}$, we investigated the scope of the process. A series of 2'-hydroxychalcones bearing electron-donor and electron withdrawing groups were

Table 2. Synthesis of diarylpropanes $\mathbf{2}$ from chalcones $\mathbf{1}$

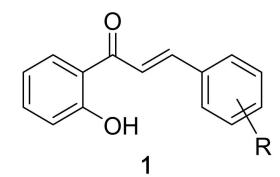

1
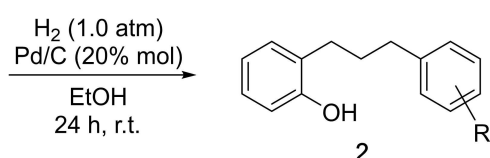

\begin{tabular}{|c|c|c|c|c|}
\hline Entry & 1 & 2 & $\mathrm{R}$ & Yield $[\%]^{[a]}$ \\
\hline 1 & $1 \mathrm{a}$ & $2 \mathbf{a}$ & $\mathrm{H}$ & 98 \\
\hline 2 & $1 \mathbf{a}$ & $2 \mathbf{a}$ & $\mathrm{H}$ & $7^{[b]}$ \\
\hline 3 & $1 \mathbf{a}$ & $2 \mathbf{a}$ & $\mathrm{H}$ & $6^{[\mathrm{c}]}$ \\
\hline 4 & $1 \mathrm{~b}$ & $2 \mathrm{~b}$ & $2-F$ & 88 \\
\hline 5 & $1 \mathrm{c}$ & $2 \mathrm{c}$ & $3-F$ & 89 \\
\hline 6 & $1 \mathrm{~d}$ & $2 d$ & $4-F$ & 90 \\
\hline 7 & $1 \mathrm{e}$ & $2 \mathrm{e}$ & $4-\mathrm{Cl}$ & 93 \\
\hline 8 & $1 \mathrm{f}$ & $2 f$ & $4-\mathrm{Br}$ & 91 \\
\hline 9 & $1 \mathrm{~g}$ & $2 \mathrm{~g}$ & 2-MeO & $84^{[\mathrm{d}]}$ \\
\hline 10 & $1 \mathrm{~h}$ & $2 \mathrm{~h}$ & 3-MeO & $91^{[\mathrm{d}]}$ \\
\hline 11 & $1 \mathbf{i}$ & $2 \mathrm{i}$ & 4-MeO & $91^{[\mathrm{d}]}$ \\
\hline 12 & $1 \mathbf{i}$ & $2 \mathrm{i}$ & 4-MeO & $90^{[\mathrm{c}]}$ \\
\hline 13 & $\mathbf{1} \mathbf{j}$ & $2 \mathrm{j}$ & 4-Me & $98^{[\mathrm{d}]}$ \\
\hline
\end{tabular}

${ }^{\text {[a] }}$ Isolated yield of compounds $\mathbf{2}$ based on starting materials $\mathbf{1}$.

${ }^{[b]} 10 \% \mathrm{~mol} \mathrm{Pd} / \mathrm{C}$.

[c] $5 \% \mathrm{~mol} \mathrm{Pd} / \mathrm{C}$.

${ }^{[\mathrm{d}]}$ Reaction time: $3 \mathrm{~h}$ hydrogenated over $\mathrm{Pd} / \mathrm{C} 10 \%(20 \% \mathrm{~mol})$ in ethanol at r.t. under hydrogen atmosphere, obtaining in all cases the total reduction products $\mathbf{2} \mathbf{a}-\mathbf{j}$ in good yields (Table 2). 1,3-Diarylpropanes $\mathbf{2} \mathbf{a}-\mathbf{j}$ were fully characterized by ${ }^{1} \mathrm{H}(300 \mathrm{MHz}),{ }^{13} \mathrm{C}(75 \mathrm{MHz})$ NMR spectroscopy, IR and HRMS (ESI-TOF). The physical data of known 1,3-diarylpropane $\mathbf{2}$ a were comparable to those previously reported in the literature. ${ }^{[17]}$

Interestingly, the presence of electron donor groups in the aromatic ring resulted in a dramatical increase in the reaction rate. Thus, total hydrogenation of chalcones $\mathbf{1 g}-\mathbf{j}$ only required $3 \mathrm{~h}$ to go to completion (Table 2, entries 9-11 and 13). On view of these results, we postulated that, while for chalcone 1 a the presence of a $20 \% \mathrm{~mol}$ of $\mathrm{Pd} / \mathrm{C}$ is essential for achieving a good hydrogenation rate (Table 2, entry 2), for substrates bearing electron-donor groups the catalyst loading could be lowered without affecting the yield of the total hydrogenation product. In order to demonstrate our hypothesis, the hydrogenation of chalcone $1 \mathbf{i}$ was carried out in the presence of a $5 \%$ $\mathrm{mol}$ of $\mathrm{Pd} / \mathrm{C} 10 \%$ in ethanol at r.t. under hydrogen atmosphere for $24 \mathrm{~h}$, affording desired 1,3-diarylpropane $\mathbf{2} \mathbf{i}$ in excellent yield (Table 2, entry 12).

This procedure was then extended to the synthesis of natural bussealins. For this purpose, chalcones $\mathbf{1} \mathbf{k}$ and 11 were stirred under hydrogen atmosphere in ethanol in the presence of $\mathrm{Pd} / \mathrm{C} 10 \%(5 \% \mathrm{~mol})$ at r.t. for $24 \mathrm{~h}$ to provide Bussealin C (2 k) and Bussealin D (2 I), respectively, in excellent yields (Scheme 1). On addition, the procedure was amenable to scale up, allowing the synthesis of multigram quantities of bussealins $\mathrm{C}$ and $\mathrm{D}(2.40 \mathrm{~g}$ and $2.27 \mathrm{~g}$, respectively). All the spectroscopic data of the synthetized bussealins match those of the isolated natural compounds. ${ }^{[9]}$

It is noteworthy that while the synthesis of Bussealin A was previously reported in the
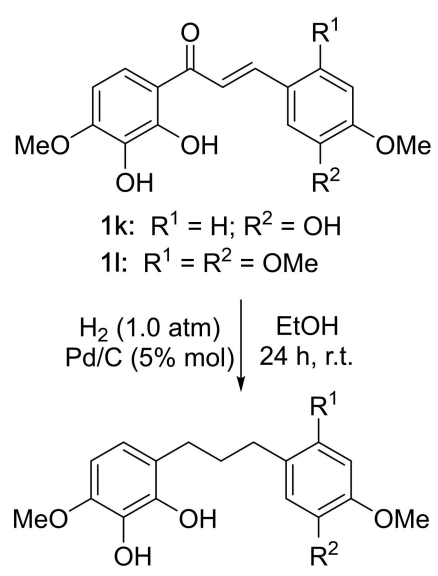

2k: $\mathrm{R}^{1}=\mathrm{H} ; \mathrm{R}^{2}=\mathrm{OH}(90 \%)$

2l: $R^{1}=R^{2}=$ OMe $(94 \%)$

Scheme 1. Synthesis of Bussealins C and D. 
literature, ${ }^{[10]}$ to the best of our knowledge this is the first report on the preparation of Bussealins $C$ and D.

Once our main goal has been achieved, we decided to further investigate the selective partial hydrogenation of the enone group. Intrigued by the possibility of controlling the outcome of the hydrogenation reaction of 2'-hydroxychalcones $\mathbf{1}$ just by changing the solvent, we studied next the generality of the process for various starting 2'-hydroxychalcones bearing electrondonor and electron-withdrawing groups.

Thus, we initiated our studies with the selective hydrogenation of the double bond to obtain dihydrochalcones. In this case, the reaction is also amenable to a decrease in the catalyst loading to $5 \% \mathrm{~mol}$ of $\mathrm{Pd} / \mathrm{C}$. Thus, when chalcones $\mathbf{1}$ were stirred at r.t. under hydrogen atmosphere for $24 \mathrm{~h}$ in DCM and in the presence of $\mathrm{Pd} / \mathrm{C} 10 \%(5 \% \mathrm{~mol})$, the corresponding

Table 3. Synthesis of dihydrochalcones 3 from chalcones 1 .

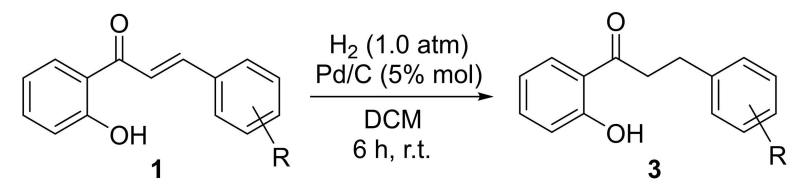

\begin{tabular}{lllll}
\hline Entry & $\mathbf{1}$ & $\mathbf{3}$ & $\mathrm{R}$ & Yield $[\%]^{[\mathrm{a}]}$ \\
1 & $\mathbf{1} \mathbf{a}$ & $\mathbf{3 a}$ & $\mathrm{H}$ & 98 \\
2 & $\mathbf{1 b}$ & $\mathbf{3 b}$ & $2-\mathrm{F}$ & 86 \\
3 & $\mathbf{1 c}$ & $\mathbf{3 c}$ & $3-\mathrm{F}$ & 85 \\
4 & $\mathbf{1 d}$ & $\mathbf{3 d}$ & $4-\mathrm{F}$ & 80 \\
5 & $\mathbf{1 e}$ & $\mathbf{3 e}$ & $4-\mathrm{Cl}$ & 83 \\
6 & $\mathbf{1 f}$ & $\mathbf{3 f}$ & $4-\mathrm{Br}$ & 94 \\
7 & $\mathbf{1 g}$ & $\mathbf{3 g}$ & $2-\mathrm{MeO}$ & 88 \\
8 & $\mathbf{1 ~ h}$ & $\mathbf{3 h}$ & $3-\mathrm{MeO}$ & 88 \\
9 & $\mathbf{1 i}$ & $\mathbf{3 i}$ & $4-\mathrm{MeO}$ & 92 \\
10 & $\mathbf{1 j}$ & $\mathbf{3 j}$ & $4-\mathrm{Me}$ & 89 \\
\hline
\end{tabular}

${ }^{\text {[a] }}$ Isolated yield of compounds $\mathbf{3}$ based on starting materials $\mathbf{1}$.

Table 4. Synthesis of 1,3-diarylpropanols 4 from chalcones $\mathbf{1}$.

\begin{tabular}{llllll} 
& & & & \\
\hline
\end{tabular}

${ }^{[a]}$ Ratio of hydrogenation products determined by ${ }^{1} \mathrm{H}$ NMR $(300 \mathrm{MHz})$ of the crude reaction mixtures.

${ }^{[b]}$ Isolated yield of compounds $\mathbf{4}$ based on starting materials $\mathbf{1}$. dihydrochalcones $\mathbf{3}$ were obtained in excellent yield (Table 3).

The physical data of known dihydrochalcones $\mathbf{3 a}$, $\mathbf{3 e}-\mathbf{f}$ and $\mathbf{3} \mathbf{h}-\mathbf{i}$ were comparable to those previously reported in the literature. ${ }^{[31]}$ Dihydrochalcones $\mathbf{3} \mathbf{b}-\mathbf{d}$, $\mathbf{3} \mathbf{g}$ and $\mathbf{3}$ j were fully characterized by ${ }^{1} \mathrm{H}(300 \mathrm{MHz})$, ${ }^{13} \mathrm{C}(75 \mathrm{MHz})$ NMR spectroscopy, IR, and HRMS (ESI-TOF).

We investigated next the generality of the selective partial hydrogenation of the enone moiety to the corresponding alcohol. Thus, a mixture of chalcones $\mathbf{1}$ and $\mathrm{Pd} / \mathrm{C} 10 \%(20 \% \mathrm{~mol})$ in $n-\mathrm{BuOH} / \mathrm{H}_{2} \mathrm{O}(1: 1)$ was stirred at r.t. under hydrogen atmosphere for $24 \mathrm{~h}$ (Table 4). Hydrogenation of chalcones bearing electron-withdrawing groups in the aromatic ring afforded desired 2,2'-dihydroxy-1,3-diarylpropanes $\mathbf{4}$ as the major hydrogenation products (Table 4, entries 2-6), whereas hydrogenation of substrates with electrondonor substituents results in the total reduction of the enone group, affording 1,3-diarylpropanes as the sole products. 1,3-Diarylpropanol 4 a was previously described in the literature. ${ }^{[32]} \mathrm{New}$ 1,3-diarylpropanols $4 \mathbf{b}-\mathbf{g}$ were fully characterized by ${ }^{1} \mathrm{H}(300 \mathrm{MHz}),{ }^{13} \mathrm{C}$ (75 MHz) NMR spectroscopy, IR, and HRMS (ESITOF).

These results can be explained considering that 2'hydroxychalcones can undergo chalcone-flavanone equilibrium under the catalytic hydrogenation conditions. The hydrogenation of chalcones start with the reduction of the $\mathrm{C}=\mathrm{C}$ bond, which is relatively fast. On contrary, the hydrogenation of flavanones requires the hydrogenolysis of the cyclic $\mathrm{C}-\mathrm{O}$ bond, which is widely assumed to be considerably more difficult. ${ }^{[33]}$

The presence of electron-donor groups causes the $\beta$-carbon to be less electrophilic, thus hindering the formation of the flavanone ring and increasing the hydrogenation rate. On contrary, electron-withdrawing substituents enhance the electrophilicity of $\beta$-carbon, facilitating the formation of the flavanone and slowing down the hydrogenation reaction.

The presence of the three possible products from the enone reduction provides new insights into the dependence of the hydrogenation rate on the reaction media. These results suggest a mechanism for the formation of 1,3-diarylpropanes $\mathbf{2}$ from chalcones $\mathbf{1}$ that proceeds via reduction of the initially formed dihydrochalcones 3 to 1,3-diarylpropanols $\mathbf{4}$, which are subsequently dehydrogenated to the total reduced products 2. Depending on the hydrogenation rate, which in turn depends on the physico-chemical properties of the solvent used (Figure 2), the hydrogenation of the enone group can go to completion to form the corresponding propane moiety or can stop at any intermediate hydrogenation products (ketone or alcohol moieties).

To confirm this hypothesis each reaction step was then separately investigated. Thus, when dihydrochal- 
cone $3 \mathbf{a}$ was hydrogenated in a mixture $n-\mathrm{BuOH} / \mathrm{H}_{2} \mathrm{O}$ (1:1) in the presence of a $\mathrm{Pd} / \mathrm{C}, 1,3$-diarylpropanol $\mathbf{4}$ a was obtained quantitatively (Scheme 2). On contrary, when the hydrogenation was performed in neat $\mathrm{EtOH}$, 1,3-diarylpropane $\mathbf{2}$ a was the only product detected in the reaction mixture. On addition, $\mathrm{Pd} / \mathrm{C}$-catalyzed hydrogenation of 1,3-diarylpropanol $\mathbf{4 a}$ afforded exclusively 1,3-diarylpropane $\mathbf{2}$ a. These results are in agreement with the proposed mechanism and further confirm the correlation between the reaction media and the hydrogenation rate, highlighting the importance of selecting a proper solvent system to selectively obtain a certain product in the hydrogenation of enone groups.

\section{Conclusions}

In conclusion, we have developed a new procedure for the effective total hydrogenation of the enone group of 2'-hydroxychalcones. The reaction proceeds, in ethanol, at atmospheric pressure and under mild conditions and tolerates a wide variety of functional groups and substitution patterns. This procedure described herein offers a straightforward, simple and cost-effective method for the preparation of a wide variety of 1,3-diarylpropanes. Using this approach, we prepared natural Bussealins $\mathrm{C}$ and $\mathrm{D}$ with a route that allows their multigram preparation; a full biological evaluation of these two natural products is underway and will be reported in due course.

On addition, we described the solvent-controlled hydrogenation of 2'-hydroxychalcones to obtain different intermediate hydrogenation products. Thus, using dichloromethane as a solvent afforded dihydrochalcones exclusively in excellent yields. On contrary, when starting chalcones were hydrogenated in a mixture of $n-\mathrm{BuOH} / \mathrm{H}_{2} \mathrm{O}(1: 1)$, the corresponding 1,3diarylpropanols were obtained in moderate to good

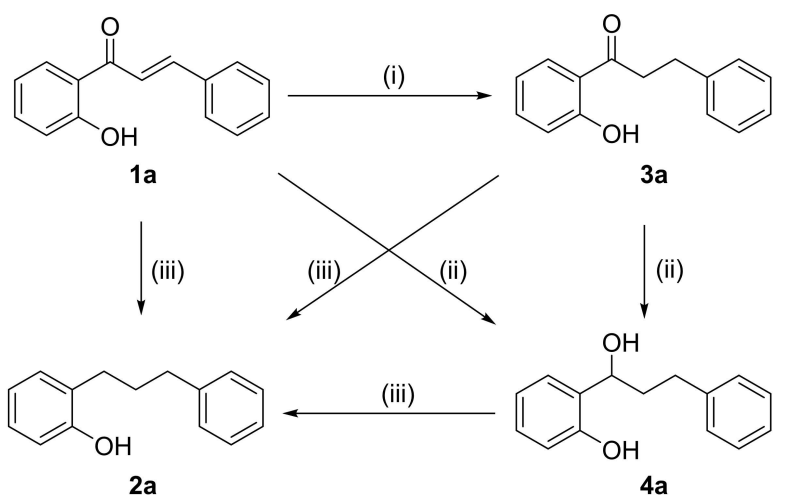

Scheme 2. Reagents and conditions: (i) $\mathrm{H}_{2}(\mathrm{~g})(1.0 \mathrm{~atm}), \mathrm{Pd} / \mathrm{C}$ (5\% mol), DCM, 6 h, r.t., $>98 \%$; (ii) $\mathrm{H}_{2}($ g) $(1.0 \mathrm{~atm}), \mathrm{Pd} / \mathrm{C}$ $(20 \% \mathrm{~mol}), n-\mathrm{BuOH} / \mathrm{H}_{2} \mathrm{O}(1: 1), 24$ h, r.t., $>98 \%$; (iii) $\mathrm{H}_{2}(g)$ (1.0 atm), $\mathrm{Pd} / \mathrm{C}(20 \% \mathrm{~mol}), \mathrm{EtOH}, 24$ h, r.t., $>98 \%$. yields. Studies aimed towards fully delineating the factors involved in these transformations are currently under investigation in our laboratory.

\section{Experimental Section}

All reagents were purchased in the highest quality available and were used without further purification. Column chromatography was carried out on silica gel 230-400 mesh. Compounds were visualized on analytical thin layer chromatograms (TLC) by UV light $(254 \mathrm{~nm})$ and potassium permanganate stain. NMR experiments were registered in an AV-Bruker spectrometer $\left({ }^{1} \mathrm{H}-\mathrm{NMR}\right.$, $300 \mathrm{MHz},{ }^{13} \mathrm{C}-\mathrm{NMR}$ and DEPT-135, $75 \mathrm{MHz}$ ). Chemical shifts are given in ppm relative to the residual non deuterated solvent, which is used as an internal standard, and coupling constants $(J)$ are reported in Hz. Diastereoisomeric ratios were obtained using ${ }^{1} \mathrm{H}-\mathrm{NMR}(300 \mathrm{MHz})$ analysis of crude products. HRMS were measured at $70 \mathrm{eV}$ using electrospray ionization in positive mode $\left(\mathrm{ESI}^{+}\right)$.

\section{General Procedure for the Synthesis of Diarylpro- panes $2 \mathbf{a}-\mathbf{j}$ from Chalcones $1 \mathbf{a}-\mathbf{j}$.}

$10 \% \mathrm{Pd} / \mathrm{C}$ (210 $\mathrm{mg}, 0.2 \mathrm{mmol} \mathrm{Pd})$ was added to a deoxygenated solution of the corresponding 2'-hydroxychalcone $\mathbf{1} \mathbf{a}-\mathbf{j}$ $(1.0 \mathrm{mmol})$ in ethanol $(20 \mathrm{~mL})$ under inert atmosphere. The reaction flask was thrice evacuated and flushed with hydrogen gas and the resulting mixture was stirred at room temperature under hydrogen atmosphere. After $24 \mathrm{~h}$, the mixture was filtered through a Celite ${ }^{\mathbb{R}}$ pad and the solvent was removed under reduced pressure, to afford the corresponding 1,3-diarylpropanes $2 \mathbf{a}-\mathbf{j}$ (84-98\% yield). 1,3-Diarylpropane $\mathbf{2}$ a was previously described in the literature. ${ }^{[17]}$ The data for new $1,3-$ diarylpropanes $\mathbf{2} \mathbf{b}-\mathbf{j}$ are shown below.

2-[3-(2-Fluorophenyl)propyl]phenol (2 b): $203 \mathrm{mg}, 88 \%$ yield. Colorless oil. $\mathrm{R}_{\mathrm{f}}=0.60$ (Hex:EtOAc 3:1). ${ }^{1} \mathrm{H}-\mathrm{NMR}(300 \mathrm{MHz}$, $\left.\mathrm{CDCl}_{3}\right): \delta 7.25-7.04(\mathrm{~m}, 6 \mathrm{H}), 6.91(\mathrm{td}, J=7.5 \mathrm{~Hz}, J=1.2 \mathrm{~Hz}$, $1 \mathrm{H}), 6.80-6.77(\mathrm{~m}, 1 \mathrm{H}), 2.79-2.68(\mathrm{~m}, 4 \mathrm{H}), 2.05-1.95(\mathrm{~m}, 2 \mathrm{H})$. ${ }^{13} \mathrm{C}-\mathrm{NMR}\left(75 \mathrm{MHz}, \mathrm{CDCl}_{3}\right): \delta 161.2(\mathrm{~d}, J=244.2 \mathrm{~Hz}), 153.4$, $130.6(\mathrm{~d}, J=5.3 \mathrm{~Hz}), 130.2,129.1 \quad(\mathrm{~d}, J=15.9 \mathrm{~Hz}), 128.0$, $127.4(\mathrm{~d}, J=8.0 \mathrm{~Hz}), 127.2,123.9(\mathrm{~d}, J=3.5 \mathrm{~Hz}), 120.8,115.3$, $115.2(\mathrm{~d}, J=22.1 \mathrm{~Hz}), 29.9,29.6,28.8(\mathrm{~d}, J=2.4 \mathrm{~Hz})$. ESITOF-HRMS: $[\mathrm{M}+\mathrm{H}]^{+}$calcd. for $\mathrm{C}_{15} \mathrm{H}_{16} \mathrm{FO}$ 231.1180; found, 231.1182 .

2-[3-(3-Fluorophenyl)propyl]phenol (2 c): $204 \mathrm{mg}, 89 \%$ yield. Colourless oil. $\mathrm{R}_{\mathrm{f}}=0.60$ (Hex:EtOAc 3:1). ${ }^{1} \mathrm{H}-\mathrm{NMR}(300 \mathrm{MHz}$, $\left.\mathrm{CDCl}_{3}\right): \delta 7.30-7.20(\mathrm{~m}, 1 \mathrm{H}), 7.17-7.07(\mathrm{~m}, 2 \mathrm{H}), 7.00(\mathrm{dd}, J=$ $7.1 \mathrm{~Hz}, J=1.3 \mathrm{~Hz}, 1 \mathrm{H}), 6.97-6.86(\mathrm{~m}, 3 \mathrm{H}), 6.77$ (dd, $J=$ $7.9 \mathrm{~Hz}, J=1.2 \mathrm{~Hz}, 1 \mathrm{H}), 4.76(\mathrm{bs}, 1 \mathrm{H}), 2.79-2.59(\mathrm{~m}, 4 \mathrm{H})$, 2.03-1.93 (m, 2H). ${ }^{13} \mathrm{C}-\mathrm{NMR}\left(75 \mathrm{MHz}, \mathrm{CDCl}_{3}\right): \delta 162.9(\mathrm{~d}, J=$ $245.3 \mathrm{~Hz}), 153.4,144.9(\mathrm{~d}, J=7.0 \mathrm{~Hz}), 130.2,129.6(\mathrm{~d}, J=$ $8.3 \mathrm{~Hz}), 127.9,127.2,124.1(\mathrm{~d}, J=2.7 \mathrm{~Hz}), 120.8115 .3,115.2$ $(\mathrm{d}, J=20.9 \mathrm{~Hz}), 112.6(\mathrm{~d}, J=21.1 \mathrm{~Hz}), 35.3,30.9,29.5$. ESITOF-HRMS: $[\mathrm{M}+\mathrm{H}]^{+}$calcd. for $\mathrm{C}_{15} \mathrm{H}_{16} \mathrm{FO}$ 231.1180; found, 231.1182 .

2-[3-(4-Fluorophenyl)propyl]phenol (2 d): $207 \mathrm{mg}, 90 \%$ yield. Colourless oil. $\mathrm{R}_{\mathrm{f}}=0.58$ (Hex:EtOAc 3:1). ${ }^{1} \mathrm{H}-\mathrm{NMR}(300 \mathrm{MHz}$, $\left.\mathrm{CDCl}_{3}\right): \delta 7.23-7.11(\mathrm{~m}, 4 \mathrm{H}), 7.05-6.87(\mathrm{~m}, 3 \mathrm{H}), 6.79(\mathrm{dd}, J=$ $7.8 \mathrm{~Hz}, J=1.3 \mathrm{~Hz}, 1 \mathrm{H}), 4.96$ (bs, 1H), 2.74-2.65 (m, 4H), 
$2.04-1.93(\mathrm{~m}, 2 \mathrm{H}) .{ }^{13} \mathrm{C}-\mathrm{NMR}\left(75 \mathrm{MHz}, \mathrm{CDCl}_{3}\right): \delta 161.2(\mathrm{~d}, J=$ $243.2 \mathrm{~Hz}), 153.4,130.3,129.7(\mathrm{~d}, J=7.7 \mathrm{~Hz}), 129.3,128.1$, 127.2, 120.8, 115.3, $1150.0(\mathrm{~d}, J=20.9 \mathrm{~Hz}), 34.8,31.4,29.5$. ESI-TOF-HRMS: $[\mathrm{M}+\mathrm{H}]^{+}$calcd. for $\mathrm{C}_{15} \mathrm{H}_{16} \mathrm{FO} 231.1180$; found, 231.1181

2-[3-(4-Chlorophenyl)propyl]phenol (2 e): $229 \mathrm{mg}, 93 \%$ yield. Colorless oil. $\mathrm{R}_{\mathrm{f}}=0.62$ (Hex:EtOAc 3:1). ${ }^{1} \mathrm{H}-\mathrm{NMR}(300 \mathrm{MHz}$, $\left.\mathrm{CDCl}_{3}\right): \delta 7.38-7.11(\mathrm{~m}, 6 \mathrm{H}), 6.94(\mathrm{td}, J=7.5 \mathrm{~Hz}, J=1.2 \mathrm{~Hz}$ $1 \mathrm{H}), 6.80(\mathrm{dd}, J=8.0 \mathrm{~Hz}, J=1.2 \mathrm{~Hz}, 1 \mathrm{H}), 4.83$ (bs, $1 \mathrm{H}), 2.78$ $2.68(\mathrm{~m}, 4 \mathrm{H}), 2.05-2.00(\mathrm{~m}, 2 \mathrm{H}) .{ }^{13} \mathrm{C}-\mathrm{NMR}\left(75 \mathrm{MHz}, \mathrm{CDCl}_{3}\right)$ : $\delta 153.4,142.3,130.2,129.8,128.5,128.4,127.2,125.8,120.9$, 115.3, 35.6, 31.3, 29.5. ESI-TOF-HRMS: $[\mathrm{M}+\mathrm{H}]^{+}$calcd. for $\mathrm{C}_{15} \mathrm{H}_{15} \mathrm{ClO}$ 247.0889; found, 247.0890.

2-[3-(4-Bromophenyl)propyl]phenol (2 f): $265 \mathrm{mg}, 91 \%$ yield. Colorless oil. $\mathrm{R}_{\mathrm{f}}=0.62$ (Hex:EtOAc 3:1). ${ }^{1} \mathrm{H}-\mathrm{NMR}(300 \mathrm{MHz}$, $\left.\mathrm{CDCl}_{3}\right): \delta 7.36-7.31(\mathrm{~m}, 2 \mathrm{H}), 7.26-7.20(\mathrm{~m}, 2 \mathrm{H}), 7.17-7.12(\mathrm{~m}$ $1 \mathrm{H}), 7.11(\mathrm{dd}, J=7.7 \mathrm{~Hz}, J=1.6 \mathrm{~Hz}, 1 \mathrm{H}), 6.91(\mathrm{td}, J=7.4 \mathrm{~Hz}$, $J=1.0 \mathrm{~Hz}, 1 \mathrm{H}), 6.78(\mathrm{dd}, J=7.9 \mathrm{~Hz}, J=0.9 \mathrm{~Hz}, 1 \mathrm{H}), 4.76(\mathrm{bs}$, $1 \mathrm{H}), 2.76-2.67(\mathrm{~m}, 4 \mathrm{H}), 2.01(\mathrm{tt}, J=9.2 \mathrm{~Hz}, J=6.9 \mathrm{~Hz}, 2 \mathrm{H})$ ${ }^{13} \mathrm{C}-\mathrm{NMR} \quad\left(75 \mathrm{MHz}, \mathrm{CDCl}_{3}\right): \delta 153.4,142.2,130.2,128.4$, 128.3, 128.1, 127.3, 125.7, 120.8, 115.2, 35.6, 31.2, 29.5. ESITOF-HRMS: $[\mathrm{M}+\mathrm{H}]^{+}$calcd. for $\mathrm{C}_{15} \mathrm{H}_{16} \mathrm{BrO} 290.0352$, found, 290.0354

2-[3-(2-Methoxyphenyl)propyl]phenol (2 g): $203 \mathrm{mg}, \quad 84 \%$ yield. Colorless oil. $\mathrm{R}_{\mathrm{f}}=0.55$ (Hex:EtOAc 3:1). ${ }^{1} \mathrm{H}-\mathrm{NMR}$ $\left(300 \mathrm{MHz}, \mathrm{CDCl}_{3}\right): \delta 7.28-7.19(\mathrm{~m}, 3 \mathrm{H}), 7.14(\mathrm{t}, J=7.7 \mathrm{~Hz}$ $1 \mathrm{H}), 6.99-6.91(\mathrm{~m}, 3 \mathrm{H}), 6.81(\mathrm{dd}, J=8.0 \mathrm{~Hz}, J=1.2 \mathrm{~Hz}, 1 \mathrm{H})$, 5.08 (bs, 1H), $3.88(\mathrm{~s}, 3 \mathrm{H}), 2.81-2.70(\mathrm{~m}, 4 \mathrm{H}), 2.06-1.95(\mathrm{~m}$, $2 \mathrm{H}) .{ }^{13} \mathrm{C}-\mathrm{NMR}\left(75 \mathrm{MHz}, \mathrm{CDCl}_{3}\right): \delta 157.5,153.6,130.7,130.1$, $129.9,128.4,127.1,127.0,120.7,120.5,115.3,110.5,55.4$ 30.1，29.7， 29.6. ESI-TOF-HRMS: $[\mathrm{M}+\mathrm{H}]^{+}$calcd. for $\mathrm{C}_{16} \mathrm{H}_{19} \mathrm{O}_{2}$ 243.1380; found, 243.1378.

2-[3-(3-Methoxyphenyl)propyl]phenol (2 h): $220 \mathrm{mg}, \quad 91 \%$ yield. Colorless oil. $\mathrm{R}_{\mathrm{f}}=0.55$ (Hex:EtOAc 3:1). ${ }^{1} \mathrm{H}-\mathrm{NMR}$ $\left(300 \mathrm{MHz}, \mathrm{CDCl}_{3}\right): \delta 7.25(\mathrm{t}, J=7.7 \mathrm{~Hz}, 1 \mathrm{H}), 7.18-7.09(\mathrm{~m}$, 2H), 6.94-6.77 (m, 5H), 3.84 (s, 3H), 2.74-2.67 (m, 4H), 2.04 $1.98(\mathrm{~m}, 2 \mathrm{H}) .{ }^{13} \mathrm{C}-\mathrm{NMR}\left(75 \mathrm{MHz}, \mathrm{CDCl}_{3}\right): \delta 159.6,153.5$, $143.9,130.2,129.3,128.2,127.1,120.9,120.8,115.2,114.2$, 111.1, 55.2, 35.6, 31.1, 29.5. ESI-TOF-HRMS: $[\mathrm{M}+\mathrm{H}]^{+}$calcd. for $\mathrm{C}_{16} \mathrm{H}_{19} \mathrm{O}_{2}$ 243.1380; found, 243.1380.

2-[3-(4-Methoxyphenyl)propyl]phenol (2 i): $221 \mathrm{mg}, \quad 91 \%$ yield. Colorless oil. $\mathrm{R}_{\mathrm{f}}=0.52$ (Hex:EtOAc 3:1). ${ }^{1} \mathrm{H}-\mathrm{NMR}$ $\left(300 \mathrm{MHz}, \mathrm{CDCl}_{3}\right): \delta 7.19(\mathrm{~d}, J=8.6 \mathrm{~Hz}, 1 \mathrm{H}), 7.13(\mathrm{dd}, J=$ $7.7 \mathrm{~Hz}, J=1.7 \mathrm{~Hz}, 1 \mathrm{H}), 6.95(\mathrm{dd}, J=7.5 \mathrm{~Hz}, J=1.2 \mathrm{~Hz}, 1 \mathrm{H})$, $6.91(\mathrm{~d}, J=8.6 \mathrm{~Hz}, 2 \mathrm{H}), 6.80(\mathrm{dd}, J=7.9 \mathrm{~Hz}, J=1.3 \mathrm{~Hz}, 1 \mathrm{H})$, 5.19 (bs, $1 \mathrm{H}), 3.86(\mathrm{~s}, 3 \mathrm{H}), 2.74-2.68(\mathrm{~m}, 4 \mathrm{H}), 2.25-1.77(\mathrm{~m}$, 2H). ${ }^{13} \mathrm{C}-\mathrm{NMR}\left(75 \mathrm{MHz}, \mathrm{CDCl}_{3}\right): \delta 157.6,153.6,134.5,130.4$, $129.4,128.4,121.5,120.8,115.3,113.8,55.4,34.7,31.5,29.5$. ESI-TOF-HRMS: $[\mathrm{M}+\mathrm{H}]^{+}$calcd. for $\mathrm{C}_{16} \mathrm{H}_{19} \mathrm{O}_{2}$ 243.1385; found, 243.1386 .

2-[3-(4-Methylphenyl)propyl]phenol (2 j): $222 \mathrm{mg}, 98 \%$ yield. Colorless oil. $\mathrm{R}_{\mathrm{f}}=0.62$ (Hex:EtOAc 3:1). ${ }^{1} \mathrm{H}-\mathrm{NMR}(300 \mathrm{MHz}$, $\left.\mathrm{CDCl}_{3}\right): \delta 7.23-7.10(\mathrm{~m}, 6 \mathrm{H}), 6.95(\mathrm{td}, J=7.4 \mathrm{~Hz}, J=1.2 \mathrm{~Hz}$ $1 \mathrm{H}), 6.80(\mathrm{dd}, J=7.9 \mathrm{~Hz}, J=1.2 \mathrm{~Hz}, 1 \mathrm{H}), 4.87$ (bs, 1H), 2.75$2.69(\mathrm{~m}, 4 \mathrm{H}), 2.40(\mathrm{~s}, 3 \mathrm{H}), 2.07-1.97(\mathrm{~m}, 2 \mathrm{H}) .{ }^{13} \mathrm{C}-\mathrm{NMR}$ $\left(75 \mathrm{MHz}, \mathrm{CDCl}_{3}\right): \delta 153.5,139.2,135.2,130.2,139.1,128.4$, $128.2,127.1,120.8,115.3,35.2,31.4,29.5,21.1$. ESI-TOF-
HRMS: $[\mathrm{M}+\mathrm{H}]^{+}$calcd. for $\mathrm{C}_{16} \mathrm{H}_{19} \mathrm{O}$ 227.1436; found, 227.1432 .

\section{Synthesis of Bussealin C (2 k)}

$10 \% \mathrm{Pd} / \mathrm{C}(0.41 \mathrm{~g}, 0.39 \mathrm{mmol} \mathrm{Pd})$ was added to a deoxygenated solution of the corresponding 2'-hydroxychalcone $1 \mathbf{k}(2.50 \mathrm{~g}$, $7.91 \mathrm{mmol})$ in ethanol $(150 \mathrm{~mL})$ under inert atmosphere. The reaction flask was thrice evacuated and flushed with hydrogen gas and the resulting mixture was stirred at room temperature under hydrogen atmosphere. After $24 \mathrm{~h}$, the mixture was filtered through a Celite ${ }^{\circledR}$ pad and the solvent was removed under reduced pressure, to afford the corresponding Bussealin C (2 k) (2.40 g, 90\% yield).

Brown solid. mp: $=79-83{ }^{\circ} \mathrm{C} . \mathrm{R}_{\mathrm{f}}=0.76$ (DCM:EtOAc 1:1). ${ }^{1} \mathrm{H}-$ NMR $\left(300 \mathrm{MHz}, \mathrm{CDCl}_{3}\right): \delta 6.82(\mathrm{~d}, \mathrm{~J}=2.0 \mathrm{~Hz}, 1 \mathrm{H}), 6.79(\mathrm{~d}$, $\mathrm{J}=8.2 \mathrm{~Hz}, 1 \mathrm{H}), 6.70(\mathrm{dd}, \mathrm{J}=8.2 \mathrm{~Hz}, \mathrm{~J}=2.0 \mathrm{~Hz}, 1 \mathrm{H}), 6.64(\mathrm{~d}$, $\mathrm{J}=8.4 \mathrm{~Hz}, 1 \mathrm{H}), 6.42(\mathrm{~d}, \mathrm{~J}=8.4 \mathrm{~Hz}, 1 \mathrm{H}), 5.64(\mathrm{bs}, 1 \mathrm{H}), 5.52$ (bs, 1H), 5.47 (bs, 1H), $3.88(\mathrm{~s}, 3 \mathrm{H}), 3.87(\mathrm{~s}, 3 \mathrm{H}), 2.66-2.57$ $(\mathrm{m}, 4 \mathrm{H}), 2.08-1.89(\mathrm{~m}, 2 \mathrm{H}) .{ }^{13} \mathrm{C}-\mathrm{NMR}\left(75 \mathrm{MHz}, \mathrm{CDCl}_{3}\right)$ : $\delta 145.3,145.0,144.5,142.1,136.0,132.1,122.0,119.9,119.7$, $114.7,110.5,102.3,56.1,56.0,34.9,31.5,29.1 .[\mathrm{M}+\mathrm{H}]^{+}$ calcd. for $\mathrm{C}_{17} \mathrm{H}_{21} \mathrm{O}_{5}$ 305.1384; found, 305.1381 .

\section{Synthesis of Bussealin D (2 I)}

$10 \% \mathrm{Pd} / \mathrm{C}(0.36 \mathrm{~g}, 0.35 \mathrm{mmol} \mathrm{Pd})$ was added to a deoxygenated solution of the corresponding 2'-hydroxychalcone 11 ( $2.50 \mathrm{~g}$, $6.94 \mathrm{mmol})$ in ethanol $(140 \mathrm{~mL})$ under inert atmosphere. The reaction flask was thrice evacuated and flushed with hydrogen gas and the resulting mixture was stirred at room temperature under hydrogen atmosphere. After $24 \mathrm{~h}$, the mixture was filtered through a Celite ${ }^{\circledR}$ pad and the solvent was removed under reduced pressure, to afford the corresponding Bussealin D (2l) (2.27 g, 94\% yield).

White solid. mp: $89-91{ }^{\circ} \mathrm{C} . \mathrm{R}_{\mathrm{f}}=0.80$ (DCM:EtOAc 1:1). ${ }^{1} \mathrm{H}-$ NMR $\left(300 \mathrm{MHz}, \mathrm{CDCl}_{3}\right): \delta 6.75(\mathrm{~s}, 1 \mathrm{H}), 6.66(\mathrm{~d}, \mathrm{~J}=8.4 \mathrm{~Hz}$, $1 \mathrm{H}), 6.53(\mathrm{~s}, 1 \mathrm{H}), 6.42(\mathrm{~d}, \mathrm{~J}=8.4 \mathrm{~Hz}, 1 \mathrm{H}), 5.25(\mathrm{bs}, 2 \mathrm{H}), 3.89$ $(\mathrm{s}, 3 \mathrm{H}), 3.87(\mathrm{~s}, 3 \mathrm{H}), 3.84(\mathrm{~s}, 3 \mathrm{H}), 3.81(\mathrm{~s}, 3 \mathrm{H}), 2.65-2.62(\mathrm{~m}$, $4 \mathrm{H}), 1.92-1.86(\mathrm{~m}, 2 \mathrm{H}) .{ }^{13} \mathrm{C}-\mathrm{NMR}\left(75 \mathrm{MHz} \mathrm{CDCl}_{3}\right): \delta 151.4$, $147.4,145.0,142.7,142.0,132.6,122.6,122.3,119.8,113.9$, $102.3,97.9,56.6,56.5,56.2,56.1,30.3,29.4,29.3$. ESI-TOFHRMS: $[\mathrm{M}+\mathrm{H}]^{+}$calcd. for $\mathrm{C}_{19} \mathrm{H}_{25} \mathrm{O}_{6}$ 349.1646; found, 349.1644 .

\section{General Procedure for the Synthesis of Dihydro- chalcones $3 \mathbf{a}-\mathbf{j}$ from Chalcones $1 \mathbf{a}-\mathbf{j}$}

$10 \% \mathrm{Pd} / \mathrm{C}$ (21 mg, $0.02 \mathrm{mmol} \mathrm{Pd}$ ) was added to a deoxygenated solution of the corresponding 2'-hydroxychalcone $\mathbf{1} \mathbf{a}-\mathbf{j}$ $(1.0 \mathrm{mmol})$ in heptane $(20 \mathrm{~mL})$ under inert atmosphere. The reaction flask was thrice evacuated and flushed with hydrogen gas and the resulting mixture was stirred at room temperature under hydrogen atmosphere. After $6 \mathrm{~h}$, the mixture was filtered through a Celite ${ }^{\circledR}$ pad and the solvent was removed under reduced pressure, to afford the corresponding dihydrochalcone $3 \mathbf{a}-\mathbf{j}$ without requiring any further purification ( $80-98 \%$ yield). The physical data of new dihydrochalcones $\mathbf{3} \mathbf{b}-\mathbf{d}, \mathbf{3} \mathbf{g}$ and $\mathbf{3} \mathbf{j}$ are shown below. 
3-(2-Fluorophenyl)-1-(2-hydroxyphenyl)propan-1-one (3 b): $210 \mathrm{mg}, 86 \%$ yield. Colorless oil. $\mathrm{R}_{\mathrm{f}}=0.76$ (Hex:EtOAc 3:1). ${ }^{1} \mathrm{H}-\mathrm{NMR}\left(300 \mathrm{MHz}, \mathrm{CDCl}_{3}\right): \delta 12.29(\mathrm{~s}, 1 \mathrm{H}), 7.78$ (dd, $J=$ $8.0 \mathrm{~Hz}, J=1.6 \mathrm{~Hz}, 1 \mathrm{H}), 7.49$ (ddd, $J=8.7 \mathrm{~Hz}, J=7.2 \mathrm{~Hz}, J=$ $1.6 \mathrm{~Hz}, 1 \mathrm{H}), 7.36-7.18(\mathrm{~m}, 2 \mathrm{H}), 7.15-7.04(\mathrm{~m}, 2 \mathrm{H}), 7.01(\mathrm{dd}$, $J=8.4 \mathrm{~Hz}, J=1.2 \mathrm{~Hz}, 1 \mathrm{H}), 6.90(\mathrm{ddd}, J=8.3 \mathrm{~Hz}, J=7.2 \mathrm{~Hz}$ $J=1.2 \mathrm{~Hz}, 1 \mathrm{H}), 3.36(\mathrm{t}, J=7.5 \mathrm{~Hz}, 2 \mathrm{H}), 3.12(\mathrm{t}, J=7.6 \mathrm{~Hz}$, $2 \mathrm{H}) .{ }^{13} \mathrm{C}-\mathrm{NMR}\left(75 \mathrm{MHz}, \mathrm{CDCl}_{3}\right): \delta 205.1,162.4,161.2(\mathrm{~d}, J=$ $245.5 \mathrm{~Hz}), 136.4,130.9(\mathrm{~d}, J=4.8 \mathrm{~Hz}), 129.8,130.9$ (d, $J=$ $7.8 \mathrm{~Hz}), 127.5$ (d, $J=15.6 \mathrm{~Hz}), 124.1(\mathrm{~d}, J=3.6 \mathrm{~Hz}), 119.2$, $118.9,118.5,115.4(\mathrm{~d}, J=21.7 \mathrm{~Hz}), 38.5,23.9$ (d, $J=2.6 \mathrm{~Hz})$. ESI-TOF-HRMS: $[\mathrm{M}+\mathrm{H}]^{+}$calcd. for $\mathrm{C}_{15} \mathrm{H}_{14} \mathrm{FO}_{2}$ 245.1021; found, 245.1022 .

3-(3-Fluorophenyl)-1-(2-hydroxyphenyl)propan-1-one (3 c): $207 \mathrm{mg}, 85 \%$ yield. Colorless oil. $\mathrm{R}_{\mathrm{f}}=0.75$ (Hex:EtOAc 3:1). ${ }^{1} \mathrm{H}-\mathrm{NMR}\left(300 \mathrm{MHz}, \mathrm{CDCl}_{3}\right): \delta 12.27(\mathrm{~s}, 1 \mathrm{H}), 7.77$ (dd, $J=$ $8.0 \mathrm{~Hz}, J=1.7 \mathrm{~Hz}, 1 \mathrm{H}), 7.53-7.44(\mathrm{~m}, 1 \mathrm{H}), 7.34-7.24(\mathrm{~m}, 2 \mathrm{H})$, $7.14-6.86(\mathrm{~m}, 4 \mathrm{H}), 3.36(\mathrm{t}, J=7.6 \mathrm{~Hz}, 2 \mathrm{H}), 3.09$ (t, $J=7.6 \mathrm{~Hz}$, $2 \mathrm{H}) .{ }^{13} \mathrm{C}-\mathrm{NMR} \quad\left(75 \mathrm{MHz}, \mathrm{CDCl}_{3}\right): \delta 204.6,162.9(\mathrm{~d}, J=$ $245.9 \mathrm{~Hz}), 162.4,143.3(\mathrm{~d}, J=7.0 \mathrm{~Hz}), 136.4,130.0(\mathrm{~d}, J=$ $8.4 \mathrm{~Hz}), 129.7,124.1$ (d, $J=2.8 \mathrm{~Hz}), 119.2,118.9,118.6,115.3$ $(\mathrm{d}, J=20.8 \mathrm{~Hz}), 113.2(\mathrm{~d}, J=21.0 \mathrm{~Hz}), 39.6,29.6$. ESI-TOFHRMS: $[\mathrm{M}+\mathrm{H}]^{+}$calcd. for $\mathrm{C}_{15} \mathrm{H}_{14} \mathrm{FO}_{2}$ 245.1021; found, 245.1021

3-(4-Fluorophenyl)-1-(2-hydroxyphenyl)propan-1-one (3 d): $196 \mathrm{mg}, 80 \%$ yield. White solid. $\mathrm{mp}: 46-47^{\circ} \mathrm{C}$. $\mathrm{R}_{\mathrm{f}}=0.70$ (Hex: EtOAc 3:1). ${ }^{1} \mathrm{H}-\mathrm{NMR}\left(300 \mathrm{MHz}, \mathrm{CDCl}_{3}\right): \delta 12.29(\mathrm{~s}, 1 \mathrm{H}), 7.76$ (dd, $J=8.0 \mathrm{~Hz}, J=1.7 \mathrm{~Hz}, 1 \mathrm{H}), 7.49$ (ddd, $J=8.8 \mathrm{~Hz}, J=$ $7.2 \mathrm{~Hz}, J=1.7 \mathrm{~Hz}, 1 \mathrm{H}), 7.27-7.13(\mathrm{~m}, 2 \mathrm{H}), 7.12-6.80(\mathrm{~m}, 4 \mathrm{H})$, $3.33(\mathrm{t}, J=7.5 \mathrm{~Hz}, 2 \mathrm{H}), 3.07(\mathrm{t}, J=7.5 \mathrm{~Hz}, 2 \mathrm{H}) .{ }^{13} \mathrm{C}-\mathrm{NMR}$ $\left(75 \mathrm{MHz}, \mathrm{CDCl}_{3}\right): \delta 205.1,162.5,161.5(\mathrm{~d}, J=244.1 \mathrm{~Hz})$, $136.4,129.8$ (d, $J=8.2 \mathrm{~Hz}), 129.3,119.2,118.9,118.6,115.3$ (d, $J=21.1 \mathrm{~Hz}), \quad 114.6,40.0,29.1 .[\mathrm{M}+\mathrm{H}]^{+}$calcd. for $\mathrm{C}_{15} \mathrm{H}_{14} \mathrm{FO}_{2}$ 245.1021; found, 245.1019 .

\section{3-(2-Methoxyphenyl)-1-(2-hydroxyphenyl)propan-1-one}

(3 g): $225 \mathrm{mg}, 88 \%$ yield. White solid. $\mathrm{mp}: 50-52^{\circ} \mathrm{C} ; \mathrm{R}_{\mathrm{f}}=0.70$ (Hex:EtOAc 3:1); ${ }^{1} \mathrm{H}-\mathrm{NMR}\left(300 \mathrm{MHz}, \mathrm{CDCl}_{3}\right): \delta 12.42(\mathrm{~s}, 1 \mathrm{H})$, $7.80(\mathrm{dd}, J=8.0 \mathrm{~Hz}, J=1.4 \mathrm{~Hz}, 1 \mathrm{H}), 7.48(\mathrm{t}, J=7.8 \mathrm{~Hz}, 1 \mathrm{H})$, 7.26-7.20 (m, 1H), $7.01(\mathrm{~d}, J=8.4 \mathrm{~Hz}, 1 \mathrm{H}), 6.97-6.83(\mathrm{~m}, 3 \mathrm{H})$, $3.85(\mathrm{~s}, 3 \mathrm{H}), 3.34(\mathrm{dd}, J=8.7 \mathrm{~Hz}, J=6.5 \mathrm{~Hz}, 2 \mathrm{H}), 3.07$ (dd, $J=$ $8.6 \mathrm{~Hz}, J=6.8 \mathrm{~Hz}, 2 \mathrm{H}) ;{ }^{13} \mathrm{C}-\mathrm{NMR}\left(75 \mathrm{MHz}, \mathrm{CDCl}_{3}\right): \delta 206.4$ $162.5,157.9,136.2,130.2,130.1,128.9,127.7,120.6,118.8$, 118.4, 110.2, 55.1，38.7，25.9. ESI-TOF-HRMS: $[\mathrm{M}+\mathrm{H}]^{+}$ calcd. for $\mathrm{C}_{16} \mathrm{H}_{17} \mathrm{O}_{3}$ 257.3065; found, 257.3065 .

\section{3-(3-Methoxyphenyl)-1-(2-hydroxyphenyl)propan-1-one}

(3 h): $225 \mathrm{mg}, 88 \%$ yield. White solid. mp: $45-46^{\circ} \mathrm{C} . \mathrm{R}_{\mathrm{f}}=0.70$ (Hex:EtOAc 3:1). ${ }^{1} \mathrm{H}-\mathrm{NMR}\left(300 \mathrm{MHz}, \mathrm{CDCl}_{3}\right): \delta 12.26(\mathrm{~s}, 1 \mathrm{H})$, $7.75(\mathrm{dd}, J=8.3 \mathrm{~Hz}, J=1.4 \mathrm{~Hz}, 1 \mathrm{H}), 7.46(\mathrm{td}, J=7.7 \mathrm{~Hz}, J=$ $1.3 \mathrm{~Hz}, 1 \mathrm{H}), 7.24(\mathrm{td}, J=8.0 \mathrm{~Hz}, J=1.7 \mathrm{~Hz}, 1 \mathrm{H}), 6.98(\mathrm{dd}, J=$ $8.3 \mathrm{~Hz}, J=1.1 . \mathrm{Hz}, 1 \mathrm{H}), 6.89-6.76(\mathrm{~m}, 3 \mathrm{H}), 3.80$ (s, 3H), 3.30 $(\mathrm{t}, J=7.7 \mathrm{~Hz}, 2 \mathrm{H}), 3.05(\mathrm{t}, J=7.6 \mathrm{~Hz}, 2 \mathrm{H}) .{ }^{13} \mathrm{C}-\mathrm{NMR}(75 \mathrm{MHz}$, $\left.\mathrm{CDCl}_{3}\right): \delta 205.5,162.5,159.8,142.3,136.4,132.7,129.8$, 129.6, 120.7, 118.9, 118.6, 114.3, 111.4, 55.2, 40.0, 30.1. ESITOF-HRMS: $[\mathrm{M}+\mathrm{H}]^{+}$calcd. for $\mathrm{C}_{16} \mathrm{H}_{17} \mathrm{O}_{3}$ 257.3065; found, 257.3066

3-(4-Methylphenyl)-1-(2-hydroxyphenyl)propan-1-one (3 j): $214 \mathrm{mg}, 89 \%$ yield. White solid. $\mathrm{mp}: 43-44^{\circ} \mathrm{C} . \mathrm{R}_{\mathrm{f}}=0.78$ (Hex: EtOAc 3:1). ${ }^{1} \mathrm{H}-\mathrm{NMR}\left(300 \mathrm{MHz}, \mathrm{CDCl}_{3}\right): \delta 12.41$ (s, 1H), 7.81 $(\mathrm{dd}, J=8.0 \mathrm{~Hz}, J=1.7 \mathrm{~Hz}, 1 \mathrm{H}), 7.53$ (ddd, $J=8.6 \mathrm{~Hz}, J=$ $7.2 \mathrm{~Hz}, J=1.6 \mathrm{~Hz}, 1 \mathrm{H}), 7.27-7.14(\mathrm{~m}, 4 \mathrm{H}), 7.06(\mathrm{dd}, J=$ $8.4 \mathrm{~Hz}, J=1.2 \mathrm{~Hz}, 1 \mathrm{H}), 6.95(\mathrm{ddd}, J=8.2 \mathrm{~Hz}, J=7.1 \mathrm{~Hz}, J=$ $1.2 \mathrm{~Hz}, 1 \mathrm{H}), 3.38(\mathrm{t}, J=7.6 \mathrm{~Hz}, 2 \mathrm{H}), 3.09(\mathrm{t}, J=7.7 \mathrm{~Hz}, 2 \mathrm{H})$, $2.41(\mathrm{~s}, 3 \mathrm{H}) .{ }^{13} \mathrm{C}-\mathrm{NMR}\left(75 \mathrm{MHz}, \mathrm{CDCl}_{3}\right): \delta 205.5162 .5,137.6$, 136.3,135.8, 129.9, 129.3, 128.3, 118.9, 118.6,40.2, 29.6, 21.1. ESI-TOF-HRMS: $[\mathrm{M}+\mathrm{H}]^{+}$calcd. for $\mathrm{C}_{16} \mathrm{H}_{17} \mathrm{O}_{3}$ 257.3065; found, 257.3068 .

General procedure for the synthesis of 1,3-diarylpropanols 4 a-f from chalcones 1 a-f.

$10 \% \mathrm{Pd} / \mathrm{C}$ (210 mg, $0.2 \mathrm{mmol} \mathrm{Pd})$ was added to a deoxygenated solution of the corresponding 2'-hydroxychalcone $\mathbf{1} \mathbf{a}-\mathbf{f}$ $(1.0 \mathrm{mmol})$ in a $1: 1$ mixture of $n-\mathrm{BuOH}$ and $\mathrm{H}_{2} \mathrm{O}(20 \mathrm{~mL})$ under inert atmosphere. The reaction flask was thrice evacuated and flushed with hydrogen gas and the resulting mixture was stirred at room temperature under hydrogen atmosphere. After 2-4 h, the mixture was filtered through a Celite ${ }^{\circledR}$ pad and the solvent was removed under reduced pressure, to afford the corresponding 1,3-diarylpropanols $\mathbf{4} \mathbf{a}-\mathbf{f}$ which were purified by flash column chromatography in EtOAc/heptane mixtures (38-98\% yield). 1,3-diarylpropanol $\mathbf{4 a}$ was previously described in the literature. ${ }^{[32]}$ The data for new 1,3-diarylpropanols $\mathbf{4} \mathbf{b}-\mathbf{g}$ are shown below.

2-[3-(2-Fluorophenyl)-1-hydroxypropyl]phenol

$120 \mathrm{mg}, 49 \%$ yield. Colourless oil. $\mathrm{R}_{\mathrm{f}}=0.49$ (Hex:EtOAc 3:1). ${ }^{1} \mathrm{H}-\mathrm{NMR}\left(300 \mathrm{MHz}, \mathrm{CDCl}_{3}\right): \delta 8.06(\mathrm{bs}, 1 \mathrm{H}), 7.24-6.82(\mathrm{~m}$, $8 \mathrm{H}), 4.83(\mathrm{dd}, J=8.5 \mathrm{~Hz}, J=5.2 \mathrm{~Hz}, 1 \mathrm{H}), 3.14$ (bs, $1 \mathrm{H}), 2.92-$ $2.70(\mathrm{~m}, 2 \mathrm{H}), 2.32-2.18(\mathrm{~m}, 1 \mathrm{H}), 2.15-2.03(\mathrm{~m}, 1 \mathrm{H}) .{ }^{13} \mathrm{C}-\mathrm{NMR}$ $\left(75 \mathrm{MHz}, \mathrm{CDCl}_{3}\right): \delta 161.2(\mathrm{~d}, J=244.6 \mathrm{~Hz}), 155.3,130.6(\mathrm{~d}$, $J=4.9 \mathrm{~Hz}), 129.0,128.2(\mathrm{~d}, J=15.8 \mathrm{~Hz}), 127.8(\mathrm{~d}, J=8.2 \mathrm{~Hz})$, $127.3,127.1,124.1$ (d, $J=3.4 \mathrm{~Hz}), 119.9,117.1,115.3$ (d, $J=$ $22.3 \mathrm{~Hz}$ ), 75.0, 37.2, 25.3 (d, $J=2.5 \mathrm{~Hz}$ ). ESI-TOF-HRMS: [M $+\mathrm{Na}]^{+}$calcd. for $\mathrm{C}_{15} \mathrm{H}_{16} \mathrm{FO}_{2} \mathrm{Na}$ 269.0954; found, 269.0954.

2-[3-(3-Fluorophenyl)-1-hydroxypropyl]phenol (4c): $113 \mathrm{mg}$, $46 \%$ yield. Colourless oil. $\mathrm{R}_{\mathrm{f}}=0.49$ (Hex:EtOAc $3: 1$ ). ${ }^{1} \mathrm{H}-\mathrm{NMR}$ $\left(300 \mathrm{MHz}, \mathrm{CDCl}_{3}\right): \delta 8.07$ (bs, 1H), 7.28-7.16 (m, 2H), 7.00$6.84(\mathrm{~m}, 6 \mathrm{H}), 4.80(\mathrm{dd}, J=8.1 \mathrm{~Hz}, J=5.4 \mathrm{~Hz}, 1 \mathrm{H}), 3.34(\mathrm{bs}$, $1 \mathrm{H}), 2.85-2.64(\mathrm{~m}, 2 \mathrm{H}), 2.30-2.18(\mathrm{~m}, 1 \mathrm{H}), 2.15-2.02(\mathrm{~m}, 1 \mathrm{H})$. ${ }^{13} \mathrm{C}-\mathrm{NMR}\left(75 \mathrm{MHz}, \mathrm{CDCl}_{3}\right): \delta 162.9(\mathrm{~d}, J=245.3 \mathrm{~Hz}), 155.3$, 144.0 (d, $J=7.1 \mathrm{~Hz}), 129.98$ (d, $J=8.4 \mathrm{~Hz}), 129.0,127.4$, $127.2,124.1(\mathrm{~d}, J=2.8 \mathrm{~Hz}), 120.0,117.1,115.3(\mathrm{~d}, J=$ $20.8 \mathrm{~Hz}), 112.8$ (d, $J=21.0 \mathrm{~Hz}), 74.7,38.1,31.6 . \mathrm{HRMS}(\mathrm{m} / \mathrm{z})$ : $[\mathrm{M}+\mathrm{Na}]^{+}$calcd. for $\mathrm{C}_{15} \mathrm{H}_{16} \mathrm{FO}_{2} \mathrm{Na}$ 269.0954; found, 269.0973

2-[3-(4-Fluorophenyl)-1-hydroxypropyl]phenol (4 d): $94 \mathrm{mg}$, $38 \%$ yield. White solid. $\mathrm{R}_{\mathrm{f}}=0.47$ (Hex:EtOAc 3:1). ${ }^{1} \mathrm{H}-\mathrm{NMR}$ $\left(300 \mathrm{MHz}, \mathrm{CDCl}_{3}\right): \delta 7.22-7.10(\mathrm{~m}, 3 \mathrm{H}), 7.02-6.83(\mathrm{~m}, 5 \mathrm{H})$, $4.81(\mathrm{dd}, J=8.2 \mathrm{~Hz}, J=5.4 \mathrm{~Hz}, 1 \mathrm{H}), 2.82-2.62(\mathrm{~m}, 2 \mathrm{H}), 2.30$ $2.18(\mathrm{~m}, 1 \mathrm{H}), 2.13-2.03(\mathrm{~m}, 1 \mathrm{H}) .{ }^{13} \mathrm{C}-\mathrm{NMR}\left(75 \mathrm{MHz}, \mathrm{CDCl}_{3}\right)$ : $\delta 161.3(\mathrm{~d}, J=243.7 \mathrm{~Hz}), 155.4,136.9(\mathrm{~d}, J=3.3 \mathrm{~Hz}), 129.7(\mathrm{~d}$, $J=7.8 \mathrm{~Hz}), 129.0,127.3,127.1,119.9,117.2,115.2(\mathrm{~d}, J=$ 21.0 Hz), 75.0, 38.5, 31.1. HRMS $(\mathrm{m} / \mathrm{z}):[\mathrm{M}+\mathrm{Na}]^{+}$calcd. for $\mathrm{C}_{15} \mathrm{H}_{16} \mathrm{FO}_{2} \mathrm{Na}$ 269.0954; found, 269.0941.

2-[3-(4-Chlorophenyl)-1-hydroxypropyl]phenol

$(4 \mathrm{e})$ $160 \mathrm{mg}, 61 \%$ yield. Colourless oil. $\mathrm{R}_{\mathrm{f}}=0.48$ (Hex:EtOAc $\left.3: 1\right)$; ${ }^{1} \mathrm{H}-\mathrm{NMR}\left(300 \mathrm{MHz}, \mathrm{CDCl}_{3}\right): \delta 8.05(\mathrm{bs}, 1 \mathrm{H}), 7.36-7.17(\mathrm{~m}$, $5 \mathrm{H}), 6.97-6.84(\mathrm{~m}, 3 \mathrm{H}), 4.83(\mathrm{dd}, J=8.2 \mathrm{~Hz}, J=5.5 \mathrm{~Hz}, 1 \mathrm{H})$, 3.07 (bs, 1H), 2.86-2.67 (m, 2H), 2.34-2.22 (m, 1H), 2.18-2.06 $(\mathrm{m}, 1 \mathrm{H}) ;{ }^{13} \mathrm{C}-\mathrm{NMR}\left(75 \mathrm{MHz}, \mathrm{CDCl}_{3}\right): \delta 155.4,141.3,128.9$, 
128.5, 128.4, 127.4, 127.2, 126.0, 119.9, 117.1, 75.1, 38.4, 31.9; ESI-TOF-HRMS: $[\mathrm{M}+\mathrm{Na}]^{+}$calcd. for $\mathrm{C}_{15} \mathrm{H}_{15} \mathrm{ClO}_{2} \mathrm{Na}$ 285.7315; found, 285.7311 .

2-[3-(4-Bromophenyl)-1-hydroxypropyl]phenol (4f): $172 \mathrm{mg}$ $56 \%$ yield. Light-brown solid. $\mathrm{R}_{\mathrm{f}}=0.48$ (Hex:EtOAc $3: 1$ ). ${ }^{1} \mathrm{H}-$ NMR $\left(300 \mathrm{MHz}, \mathrm{CDCl}_{3}\right): \delta 7.88(\mathrm{bs}, 1 \mathrm{H}), 7.42(\mathrm{~d}, J=8.3 \mathrm{~Hz}$, 2H), 7.19 (ddd, $J=8.7 \mathrm{~Hz}, J=7.2 \mathrm{~Hz}, J=1.9 \mathrm{~Hz}, 1 \mathrm{H}$ ), 7.09 (d, $J=8.4 \mathrm{~Hz}, 2 \mathrm{H}), 6.95-6.82(\mathrm{~m}, 3 \mathrm{H}), 4.82(\mathrm{dd}, J=8.2 \mathrm{~Hz}, J=$ $5.6 \mathrm{~Hz}, 1 \mathrm{H}), 2.84(\mathrm{bs}, 1 \mathrm{H}), 2.81-2.61(\mathrm{~m}, 2 \mathrm{H}), 2.31-2.18(\mathrm{~m}$ 1H), 2.14-2.02 (m, 1H). ${ }^{13} \mathrm{C}-\mathrm{NMR}\left(75 \mathrm{MHz}, \mathrm{CDCl}_{3}\right): \delta 155.4$, $140.5,131.5,130.2,129.1,127.2,127.1,119.9,119.7,117.2$, 75.0, 38.2, 31.3. ESI-TOF-HRMS: $[\mathrm{M}+\mathrm{H}]^{+}$calcd. for $\mathrm{C}_{15} \mathrm{H}_{14} \mathrm{BrO}_{2}$ 305.0177; found, 305.0175.

\section{Acknowledgements}

This work has received financial support from the Ministerio de Ciencia e Innovación (PID2019-109253RB-I00), Principado de Asturias (FICYT IDI/2018/000181) and the European Union (European Regional Development Fund-ERDF). Partial financial support by Arcelor Mittal (R\&D-Principado de Asturias; FUO-286-18) is gratefully acknowledged. M.S. thanks the University of Oviedo for a predoctoral contract.

\section{References}

[1] a) L. Q. Wang, M. M. Wu, J. P. Liu, Y. Li, Y. Hua, Y. Y. Wang, X. Y. Li, Y. G. Chen, J. H. Wang, Planta Med. 2011, 77, 1841-1844; b) A. Dawe, S. Pierre, D. E. Tsala, S. Habtemariam, Pharm. Crops 2013, 4, 38-59; c) S. L. Yang, X. K. Liu, Chin. Chem. Lett. 2005, 16, 57-60; d) J. B. Fernandes, M. N. S. Ribeiro, O. R. Gottlieb, H. E. Gottlieb, Phytochemistry 1980, 19, 1523-1525.

[2] M. Takasugi, M. Anetai, T. Masamune, A. Shirata, K. Takahashi, Chem. Lett. 1980, 339-340.

[3] G.-J. Huang, M. V. B. Reddy, P.-C. Kuo, C.-H. Huang, H.-C. Shih, E.-J. Lee, M.-L. Yang, Y.-L. Leu, T.-S. Wu, Eur. J. Med. Chem. 2012, 48, 371-378.

[4] E. Pan, L. Harinantenaina, P. J. Brodie, J. S. Miller, M. W. Callmander, S. Rakotonandrasana, E. Rakotobe, V. E. Rasamison, D. G. Kingston, J. Nat. Prod. 2010, 73, 1792-1795.

[5] U. J. Youn, Y. S. Lee, H. Jeong, J. Lee, J.-W. Nam, Y. J. Lee, E. S. Hwang, J.-. H. Lee, D. Lee, S. S. Kang, E.-K. Seo, J. Nat. Prod. 2009, 72, 1895-1898.

[6] P. Moosophon, S. Kanokmedhakul, K. J. Kanokmedhakul, J. Nat. Prod. 2011, 74, 2216-2218.

[7] L. Gibhard, K. Pravin, E. Abay, A. Wilhelm, K. Swart, N. Lawrence, R. Khoury, J. van der Westhuizen, P. Smith, L. Wiesner, Antimicrob. Agents Chemother. 2016, 60, 3065-3069.

[8] L. J. Simons, B. W. Caprathe, M. Callahan, J. M. Graham, T. Kimura, Y. Lai, H. LeVine, W. Lipinski, A. T. Sakkab, Y. Tasaki, L. C. Walker, T. Yasunaga, Y. Ye, N. Zhuang, C. E. Augelli-Szafran, Bioorg. Med. Chem. Lett. 2009, 19, 654-657.

[9] E. Pan, L. Harinantenaina, P. J. Brodie, J. S. Miller, M. W. Callmander, S. Rakotonandrasana, E. Rakotobe,
V. E. Rasamison, D. G. I. Kingston, J. Nat. Prod. 2010 , 73, 1792-1795.

[10] E. C. Frye, C. J. O’ Connor, D. G. Twigg, B. Elbert, L. Laraia, D. G. Hulcoop, A. R. Venkitaraman, D. R. Spring, Chem. Eur. J. 2012, 18, 8774-8779.

[11] L. Jurd, K. L. Stevens, A. D. King Jr., K. Mihara, J. Pharm. Sci. 1971, 60, 1753-1755.

[12] R. C. Ronald, C. J. Wheeler, J. Org. Chem. 1984, 49, 1658-1660.

[13] H. Y. Jang, H. J. Park, K. Damodar, J.-K. Kim, J.-G. Jun, Bioorg. Med. Chem. Lett. 2016, 26, 5438-5443.

[14] A. E. M. Noreljaleel, A. Wilhelm, S. L. Bonnet, J. H. van der Westhuizen, J. Nat. Prod. 2018, 81, 41-48.

[15] P. A. de Almeida, S. V. Fraiz Jr, R. Braz-Filho, J. Braz. Chem. Soc. 1999, 10, 347-353.

[16] A. A. Morais, R. Braz, S. V. Frais Jr, Phytochemistry 1989, 28, 239-242.

[17] H. Yuan, H. Chen, H. Jin, B. Li, R. Yue, J. Ye, Y. Shen, L. Shan, Q. Sun, W. Zhang, Tetrahedron Lett. 2013, 54, 2776-2780.

[18] D. G. Twigg, L. Baldassarre, E. C. Frye, W. R. J. D. Galloway, D. R. Spring, Org. Lett. 2018, 20, 1597-1599.

[19] a) J. J. Varghese, S. H. Mushrif, React. Chem. Eng. 2019, 4, 165-206; b) P. J. Dyson, P. G. Jessop, Catal. Sci. Technol. 2016, 6, 3302-3316.

[20] a) L. Q. Zhang, J. M. Winterbottom, A. P. Boyes, S. Raymahasay, J. Chem. Technol. Biotechnol. 1998, 72, 264-272; b) Y. Li, H. Cheng, W. Lin, C. Zhang, Q. Wu, F. Zhao, M. Arai, Catal. Sci. Technol. 2018, 8, 35803589.

[21] E. B. Maxted, V. Stone, J. Chem. Soc. 1938, 454-455.

[22] a) H. Wan, A. Vitter, R. V. Chaudhari, B. Subramaniam, J. Catal. 2014, 309, 174-184; b) B. Ren, M. Zhao, L. Dong, G. Li, Catal. Commun. 2014, 50, 92-96.

[23] M. T. Drexler, M. D. Amiridis, J. Catal. 2003, 214, 136145 .

[24] a) M. Menetrey, A. Markovits, C. Minot, Surf. Sci. 2003, 524, 49-62; b) S. Cai, K. Sohlberg, J. Mol. Catal. A 2003, 193, 157-164; c) M. M. Walz, J. Werner, V. Ekholm, N. L. Prisle, G. Öhrwall, O. Björneholm, Phys. Chem. Chem. Phys. 2016, 18, 6648-6656.

[25] F. P. Byrne, S. Jin, G. Paggiola, T. H. M. Petchey, J. H. Clark, T. J. Farmer, A. J. Hunt, C. R. McElroy, J. Sherwood, Sustain. Chem. Process 2016, 4, 7-31.

[26] a) D. J. C. Constable, C. Jiménez-González, R. K. Henderson, Org. Process Res. Dev. 2007, 11, 133-137; b) P. J. Dunn, S. Galvin, K. Hettenbach, Green Chem. 2004, 6, 43-48.

[27] a) R. K. Henderson, C. Jiménez-González, D. J. C. Constable, S. R. Alston, G. G. A. Inglis, G. Fisher, J. Sherwood, S. P. Binks, A. D. Curzons, Green Chem. 2011, 13, 854-862; b) D. Prat, O. Pardigon, H. W. Flemming, S. Letestu, V. Ducandas, P. Isnard, E. Guntrum, T. Senac, S. Ruisseau, P. Cruciani, P. Hosek, Org. Process Res. Dev. 2013, 17, 1517-1525; c) K. K. Alfonsi, J. Colberg, P. J. Dunn, T. Fevig, S. Jennings, T. A. Johnson, H. P. Kleine, C. Knight, M. A. Nagy, D. A. Perry, M. Stefaniak, Green Chem. 2008, 10, 31-36. 
[28] E. de Jong, A. Higson, P. Walsh, M. Wellish, Biofuels Bioprod. Biorefin. 2012, 6, 606-624.

[29] D. H. B. Ripin, M. Vetelino, Synlett 2003, 2353-2353.

[30] Physical properties of DCM, EtOH, $\mathrm{H}_{2} \mathrm{O}$ and $n-\mathrm{BuOH}$ : a) E. Brunner, J. Chem. Eng. Data 1985, 30, 269-273; b) C. Reichardt, Angew. Chem. Int. Ed. 1965, 4, 29-40; c) Solubility data series, vol. 5/6, Hydrogen and Deuterium, Ed. C. L. Young, Pergamon Press (values for the mixture $n-\mathrm{BuOH} / \mathrm{H}_{2} \mathrm{O}$ are estimations).
[31] a) A.-R. Ibrahim, Y. Abul-Hajj, J. Nat. Prod. 1990, 53, 644-656; b) S. Kirkiacharian, H. G. Tongo, J. Bastide, P. Bastide, M. M. Grenie, Eur. J. Med. Chem. 1989, 24, 541-546; c) M. Forghieri, C. Laggner, P. Paoli, T. Langer, G. Manao, G. Camici, L. Bondioli, F. Prati, L. Costantino, Bioorg. Med. Chem. 2009, 17, 2658-2672.

[32] T. Katagi, M. Aoki, S. Katsu, H. Kataoka, T. Hanawa, Chem. Pharm. Bull. 1990, 38, 2256-2258.

[33] H. G. Krishnamurty, S. Sathyanarayana, Synth. Commun. 1989, 19, 119-123. 


\section{FULL PAPER}

Solvent-Controlled Hydrogenation of 2'-Hydroxychalcones:

A Simple Solution to the Total Synthesis of Bussealins

Adv. Synth. Catal. 2020, 362, 1-11

M. Soto, R. G. Soengas*, H. Rodríguez-Solla*

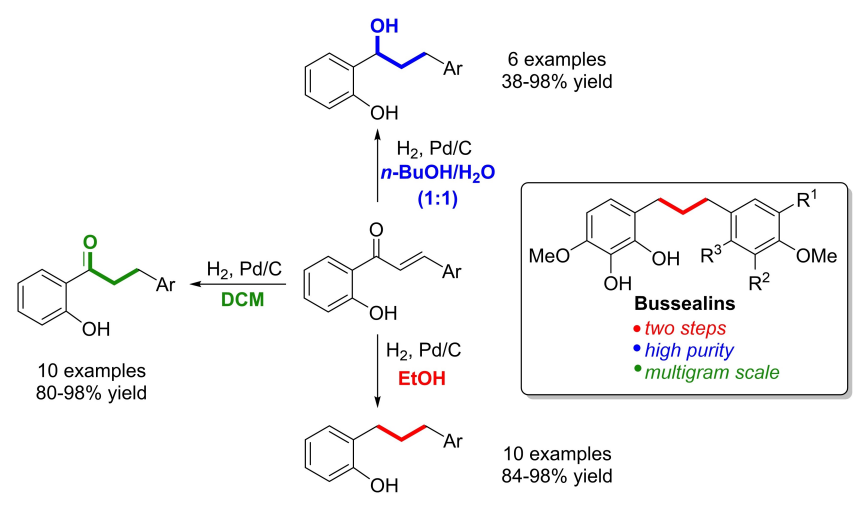

